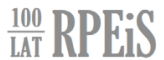

\section{RECENZOWANIE OPRACOWANIA KARNOPRAWNEGO W CZASOPIŚMIE NAUKOWYM}

Współczesne problemy funkcjonowania polskich czasopism naukowych w ramach nauk społecznych, w tym między innymi nauk prawnych, znacznie różnią się od tych sprzed dekady lub wcześniejszych. Można tutaj wskazać chociażby na dwa nowe zjawiska. Pierwsze związane jest z masowością twórczości naukowej, z której wynika znacznie większa liczba opracowań naukowych zgłaszanych do publikacji. Od razu trzeba dodać, że towarzyszy temu generalnie istotne obniżenie poziomu naukowego takich opracowań. Drugie zjawisko można ogólnie określić zbiorczym mianem „parametryzacji”, co związane jest z tym, że prowadzenie czasopisma nie jest już przede wszystkim projektem naukowym, lecz - co najmniej w tym samym stopniu - administracyjnym, by wspomnieć tutaj tylko o „punktozie” (od „psychoza” i „punktacja”, czyli w wolnym tłumaczeniu: szaleństwo parametryzacyjne). Obydwa zjawiska raczej nauce nie służa, uznać je należy jednak za już nieodwracalne.

Przedmiotem niniejszego opracowania nie jest jednak żadna z powyższych podstawowych bolączek funkcjonowania czasopism naukowych o charakterze prawniczym. Chciałbym zająć się innym - jak twierdzę - również negatywnym zjawiskiem. Związane jest ono z recenzowaniem projektowanych (zgłoszonych) publikacji naukowych. Jako członek kilku komitetów redakcyjnych i osoba recenzująca dla różnych redakcji co najmniej kilkanaście opracowań rocznie, w pierwszej kolejności zauważam, że każda redakcja stosuje własny sposób recenzji, a ściślej - własny formularz recenzyjny. Po drugie, zauważam jednocześnie, że żaden z nich (tj. funkcjonujacy na rynku wydawnictw, w tym czasopism prawniczych) nie może być uznany za w pełni prawidłowy.

Z oczywistych powodów chciałbym zajać się problematyką recenzji opracowań karnistycznych, ponieważ takimi się wyłącznie zajmuję. Należy jednak uznać, że poniższe refleksje w znacznej mierze dotyczą również generalnie problematyki recenzowania opracowania o charakterze naukowo-prawniczym.

\footnotetext{
* Robert Zawłocki, Uniwersytet im. Adama Mickiewicza w Poznaniu,
} zawlocki@amu.edu.pl, https://orcid.org/0000-0003-1798-4985. 
Odnosząc się do tytułowego zagadnienia, należy w pierwszej kolejności odnotować, że pożądane treści i wymogi recenzyjne w naturalny sposób nawiązują do pożądanej treści recenzowanego opracowania. Przedmiotem omawianej recenzji jest przecież utwór naukowy. Na tej podstawie należy także uznać, że poniższe rozważania $\mathrm{w}$ dużym stopniu dotyczą również tego, jak powinna wyglądać recenzowana analiza karnoprawna zgłoszona do czasopisma naukowego (oczywiście, w istocie jest odwrotnie, a mianowicie to utwór naukowy powinien zawierać określoną treść, a w ślad za tym - konsekwentnie również taką formalną treść powinna zawierać jego recenzja).

Recenzje mogą mieć charakter otwarty, czyli strukturę i treść w pełni zależną od jej autora, albo zamknięty - w postaci redakcyjnego formularza zawierającego ściśle określone szczegółowe elementy recenzji. Wspomniana już powyżej „punktoza” wymaga zastosowania drugiego rozwiązania, które jednak należy uznać za właściwe również z merytorycznego punktu widzenia. W tym przypadku bowiem recenzje nie tylko sa jednolite, lecz przede wszystkim zawsze zawierają odpowiednią treść. Należy jednak podkreślić, że recenzja - w swoim klasycznym (odpowiednim) znaczeniu - to samoistny utwór zawierający nie tylko samą ocenę, lecz łącznie - analizę i ocenę innego utworu. Okoliczność ta mocno determinuje strukturę i treść formularza recenzyjnego, który powinien być sformułowany tak, aby wymuszał przede wszystkim analizę, a dopiero na końcu - ocenę.

Dalsze rozważania należy traktować jako własne propozycje autora, zachęcające do głębszej refleksji i dyskusji. W każdym razie mają one charakter umowny i konwencyjny, a z pewnością nie kompletny. Wydaje się jednak, że odpowiadaja one podstawowym wymogom recenzji naukowej tekstu karnistycznego zgłoszonego do publikacji w czasopiśmie prawniczym.

Sprawdzanie każdego opracowania naukowego powinno przebiegać na dwóch płaszczyznach, a właściwie - kolejnych po sobie etapach: metodologicznym i metodycznym. Metodologia opracowania naukowego określa jego merytoryczny przedmiot, czy też wskazuje na to, czym zajmuje się jego autor. Metodyka opracowania naukowego określa zaś przyjęty przez autora sposób realizacji celu naukowego, czy też wskazuje na to, jak został opracowany merytoryczny przedmiot opracowania. Recenzja metodologii powinna odnosić się do następujących zagadnień: znaczenie tytułu, zakres tematyki, znaczenie tematyki, przedmiot analizy, problemy badawczy, założenie badawcze, hipoteza badawcza, terminologia oraz aktualny stan wiedzy. Recenzja metodyki powinna zaś odnosić się do następujących zagadnień: struktura analizy, metoda badawcza, przyjęta filozofia prawa oraz warsztat naukowy.

Konieczne jest teraz przybliżenie poszczególnych zagadnień. Zatem w zakresie metodologii należy zrecenzować następujące elementy:

1. Znaczenie tytułu. W opracowaniach naukowych nierzadko przyjęty tytuł ma charakter „hasłowy” (np. „Przestępstwo zabójstwa”). Nawet w przypadku tytułów rozwiniętych (np. zawierających podtytuł: „Analiza dogmatyczna obowiązujących przepisów polskiego prawa karnego") autor najczęściej używa różnych skrótów myślowych. Dlatego konieczne jest wskazanie już na początku opracowania pełnego znaczenia tytułu, zarówno w warstwie języko- 
wej, jak i merytorycznej. Pozwoli to odbiorcy już na wstępie lektury na pełna identyfikację naukowej istoty tytułu opracowania.

W tym właśnie elemencie należy również zbadać między innymi, czy przyjęty przez autora tytuł odpowiada treści opracowania.

2. Zakres tematyki. Tytuł, wraz z wyjaśnieniem jego znaczenia, wciąż jedynie ogólnie wskazuje na tematykę naukową opracowania. Dlatego należy ją merytorycznie przybliżyć. Tematyka karnoprawnego opracowania może odnosić się do danej instytucji prawa karnego w ujęciu węższym (np. tylko niektóre rodzaje znamion ustawowych danego typu czynu zabronionego przez ustawę pod groźbą kary) albo w ujęciu szerszym (np. w zestawieniu z innymi instytucjami - typami czynu zabronionego). Ponadto zawsze należy wskazać, czy dana tematyka jest ujmowana wyłącznie na płaszczyźnie dogmatycznej czy też innej (np. polityczno-kryminalnej, kryminologicznej, prawnoporównawczej albo historycznej). W opracowaniach prawnokarnych konieczne jest też wskazanie przez autora, czy zajmuje się daną tematyką tylko na płaszczyźnie materialnoprawnej czy też innej (procesowoprawnej lub karnowykonawczej oraz karnoskarbowej). Z daną tematyką związanych jest zazwyczaj wiele problemów (instytucji prawa karnego), dlatego też można ją wskazać w sposób negatywny, czyli przez wyliczenie zagadnień, które nie są przedmiotem danego opracowania.

3. Znaczenie tematyki. Każde opracowanie powinno być doniosłe teoretycznie oraz praktycznie. Celem nauki nie jest prowadzenie badań dla samych badań, lecz uzyskanie efektu pożytecznego społecznie. Tak też należy pojmować znaczenie tematyki opracowań karnoprawnych. Niestety, obserwacja dorobku nauki prawa karnego wskazuje w wielu przypadkach na swoista aberrację od problemów praktycznie doniosłych. Karniści nierzadko pochłonięci są wydumanymi problemami dogmatycznymi, które w pracy prawnika praktyka pojawiają się niezwykle rzadko (np. usiłowaniem nieudolnym przestępstwa lub kontratypem eksperymentu poznawczego).

Zidentyfikowanie istotnego problemu praktycznego nie jest łatwym zadaniem. Należy jednak zadać sobie ten trud, formułując naukowy problem badawczy. Nauka prawa karnego to nauka społeczna. Zajmuje się ona kwestiami, które bezpośrednio i często dotyczą zwykłych ludzi na masową skalę. Nie chodzi przy tym o to, aby karnista teoretyk zajmował się rozwiązywaniem problemów praktycznych (od tego sa karniści praktycy). Chodzi o to, aby teoretyk zajmował się problemem teoretycznym, który jednak ma doniosłość praktyczną.

Ważne jest przy tym unikanie zagadnień, które już wielokrotnie były przedmiotem pogłębionych analiz. Oryginalny charakter opracowania jest jego istotna zaletą i powinien być rozpatrywany właśnie w omawianym tutaj zakresie.

Należy również zauważyć, że z powodu wskazanej powyżej aberracji nauk, problemy doniosłe $\mathrm{w}$ teorii (nauce) prawa karnego nierzadko nie pokrywają się z problemami doniosłymi w praktyce. W rezultacie określony problem może być bardzo doniosły teoretycznie, a zupełnie marginalny dla praktyki (i odwrotnie). Optymalnym rozwiązaniem byłoby sformułowanie problemu, który wykazuje znaczną doniosłość w obydwu wyżej wskazanych aspektach. 
Nie zmienia to konieczności oceny tego aspektu opracowania odnośnie do każdego z nich.

4. Problem badawczy. Tytuł i tematyka opracowania naukowego nie określaja jeszcze problemu badawczego. Sprowadza się on bowiem do sformułowania określonej kwestii spornej wymagającej wyjaśnienia (np. materialny albo formalny charakter przestępstwa naruszenie praw pracownika z art. 218 k.k.). Zabieg ten nie jest prosty, chodzi bowiem o kwestię rzeczywiście, a nie tylko pozornie sporna. Należy tutaj w świetle nierzadkiej „,radosnej” twórczości paranaukowej podkreślić, że uprawianie nauki to nie mentalna zabawa realizujaca intelektualne potrzeby jej autora, lecz racjonalne rozwiązywanie rzeczywistych (nie mylić z praktycznymi) problemów.

$\mathrm{W}$ nauce prawa karnego $\mathrm{z}$ jednej strony sporne jest niemal wszystko, z drugiej jednak - wyszukanie realnie spornych, a przy tym oryginalnych i doniosłych teoretycznie i praktycznie problemów jest zadaniem niełatwym. Wymaga ono w pierwszej kolejności twórczego i wnikliwego zapoznania się z określoną tematyką. Należy przy tym odnotować, że skrócona formuła artykułu nie pozwala raczej na rozstrzyganie problemów doniosłych (np. o charakterze systemowym). Oznacza to, że należy dostosować problem do objętości opracowania, unikając $\mathrm{w}$ ten sposób zbyt pobieżnej analizy. Należy też unikać problemów badawczych o charakterze „incydentalnym” (tzn. dotyczacym kwestii zupełnie nieważnej lub pobocznej). W warstwie językowej najbardziej dobitnym i zarazem optymalnym oznaczeniem problemu badawczego jest sformułowanie określonego pytania (np.: czy ustawodawca odpowiednio sformułował elementy czynu ciagłego?). Truizmem jest zastrzeżenie, że pytanie to musi ściśle korespondować z tytułem i tematyką artykułu.

5. Hipoteza badawcza. Jest to istota opracowania naukowego, po to naukowiec podejmuje swój intelektualny wysiłek. Hipoteza badawcza określa więc cel rozważań. Sprowadza się ona do udzielenia sugerowanej przez autora odpowiedzi na pytanie wyznaczające problem badawczy (np. treść art. 12 jest określona w sposób błędny). Jest to więc autorska propozycja rozstrzygnięcia problemu badawczego, sprowadzająca się do wysunięcia twierdzenia rozstrzygającego podjęty problem badawczy.

Jak już wskazano, cała analiza poświęcona jest merytorycznej weryfikacji postawionej hipotezy badawczej. Weryfikacja ta może zakończyć się negatywnie - nie jest to wadą pracy naukowej, lecz czasami jej naturalnym elementem. W przypadku prawidłowo (poznawczo rzeczywiście interesujacego i oryginalnego) sformułowanego problemu badawczego negatywna weryfikacja hipotezy badawczej jest nawet cenniejsza od potwierdzenie słuszności hipotezy badawczej o niskiej jakości naukowej. Inną kwestia jest to, że w praktyce hipoteza badawcza z reguły weryfikowana jest pozytywnie. Wynik taki, przy prawidłowo sformułowanej hipotezie, jest też naukowo najbardziej pożądany.

Wydaje się przy tym, że formuła artykułu sprawia, iż tylko jedna hipoteza badawcza jest w zupełności wystarczająca.

6. Przedmiot analizy. Jest to merytoryczny punkt odniesienia analizy naukowej czy też swoista oś: tytułu, tematyki, problemu badawczego i hipo- 
tezy badawczej. Przedmiotem analizy karnoprawnej jest z reguły określony przepis prawa karnego (lub grupa przepisów). Należy zatem wskazać ten przepis prawa, a najlepiej przywołać go w przypisie.

Problem badawczy i hipoteza badawcza związane sa zazwyczaj z odpowiednią interpretacją danego przepisu karnoprawnego. Warto więc jego treść umieścić w opracowaniu.

W tym miejscu konieczne jest wskazanie przez autora stanu prawnego, czyli określenie daty, w której analizuje się dany przepis. Współczesne prawo karne jest nowelizowane średnio co tydzień, konieczne jest więc przywołanie aktualnego przepisu i wyraźne określenie badanego stanu prawnego. Często recenzja lub publikacja realizowane są w czasie, w którym opracowanie nie jest aktualne. Dlatego autor powinien wybierać tematy względnie „stabilne” naukowo, a z pewnością musi sprawdzić, czy w czasie przygotowania artykułu nie jest przygotowywana zmiana prawa w zakresie tytułowym.

7. Założenie badawcze. Każda analiza karnoprawna jest syntezą odnosząca się do określonego fragmentu wiedzy prawniczej. W opracowaniu artykułowym zasadniczo nie ma miejsca, jak również konieczności, aby wskazywać na różne, liczne twierdzenia leżące u podstaw rozważań. Można je jednak podzielić na dwie grupy: twierdzenia związane z problemem badawczym tylko pośrednio oraz związane z nim bezpośrednio. Wydaje się, że te ostatnie należy przywołać w opracowaniu. Zabieg ten z jednej strony odpowiednio „pozycjonuje" analizę, a z drugiej - pozwala autorowi zająć się bezpośrednio problemem badawczym (weryfikacją hipotezy badawczej) bez zbędnej konieczności analizowania wątków pobocznych. Bardzo często elementu tego w opracowaniach naukowych z zakresu prawa karnego brakuje. Tymczasem autor powinien sobie uświadomić ten aspekt swojej pracy badawczej chociażby po to, aby była ona bardziej trafna i rzetelna.

8. Terminologia. W nauce prawa karnego (jak to bywa w nauce prawa i wszystkich naukach społecznych) większość pojęć ma charakter sporny. Tymczasem w danym opracowaniu niektóre pojęcia moga odgrywać istotna rolę. W takim przypadku, z tych samych powodów, jak wskazane powyżej, autor powinien wyjaśnić przyjętą terminologię. Dotyczy to zwłaszcza znaczenia ważniejszych pojęć używanych przez niego do formułowania problemu badawczego i hipotezy badawczej.

9. Aktualny stan wiedzy. Autor ma obowiązek zreferowania aktualnego stanu wiedzy w zakresie objętym tematyką i problemem badawczym. Odbywa się to na dwóch poziomach. Po pierwsze, należy przywołać (i wykorzystać) podstawową literaturę i orzecznictwo w analizowanym zakresie. Po drugie, należy wskazać, jak jej przedstawiciele (a przynajmniej ich większość) odnosi się do problemu badawczego, a ściślej - jak go formułuje i rozwiąuje. Zabieg ten oczywiście wymaga wcześniejszego wnikliwego zapoznania się ze stanowiskiem doktryny i judykatury, co jest niezbędne przy właściwej identyfikacji autorskiego sformułowania problemu badawczego i hipotezy badawczej. W tym właśnie miejscu należy ocenić aktualność podjętej przez autora tematyki. 
Przywołane powyżej elementy metodologii pozwalają określić i ocenić przedmiot pracy naukowej. Poniżej przedstawione zostaną elementy metodyki wskazujące na sposób osiagnięcia celu badawczego, czy też analizy przedmiotu pracy. Zatem w zakresie metodyki należy zrecenzować następujące elementy:

1. Struktura analizy. Truizmem jest stwierdzenie, że artykuł naukowy powinien zawierać podstawowe elementy każdej pisemnej wypowiedzi, tj. wstęp, rozwinięcie oraz zakończenie. Tymczasem doświadczenie recenzenta wskazuje, że nie jest to rzecz oczywista dla znacznej części autorów. Dlatego należy ją tutaj przywołać i z cała moca podkreślić. We wstępie artykułu należałoby przywołać wszystkie potrzebne elementy z zakresu metodologii badań. Rozwinięcie powinno zawierać istotę analizy, a zakończenie - jej wnioski. W opracowaniach karnoprawnych wnioski te powinny mieć dwojaki charakter - konkluzji podsumowujących opisowo oraz - dodatkowo - postulatów de lege lata oraz postulatów de lege ferenda. Karnoprawna analiza bez takich postulatów jest zasadniczo naukowo jałowa. W podsumowaniu opracowania należy wskazać w szczególności wynikająca z rozważań weryfikację hipotezy badawczej, a następnie - niejako w konsekwencji przyjętych wniosków pozwalających na przeprowadzenie tej weryfikacji - należy pokusić się o sformułowanie określonych postulatów interpretacyjnych: odnośnie do obowiązującego prawa (de lege lata) albo prawotwórczych: odnośnie do postulowanego prawa (de lege ferenda).

Niestety relatywnie często autorzy pomijają w zakończeniu zebranie swoich cennych wniosków czy też zapominają o odniesieniu się do hipotezy badawczej. Zamiast tego kończą oni swoje wartościowe wywody banalnymi sloganami. Należy też odnotować zjawisko odwrotne, gdy autor wieńczy swoje dzieło wnioskami konkretnymi, które jednak nie mają odpowiedniego oparcia w przeprowadzonej analizie.

Struktura analizy nie dotyczy jednak wyłącznie powyższej kwestii. Przyjęty przez autora podział rozważań, z uwzględnieniem jego meritum oraz kolejności analizowanych zagadnień (np. tytułów i kolejności rozdziałów opracowania), uwidacznia dobitnie sposób analizy przyjęty przez autora. Jest to kwestia co prawda tylko formalnego sposobu rozstrzygnięcia problemu badawczego, jednakże jest ona tak samo ważna jak prawidłowe jego sformułowanie. Można bowiem wpierw właściwie określić problem badawczy i hipotezę badawczą, a następnie przez błędnie zastosowaną strukturę rozważań zniweczyć potencjał naukowy opracowania. Ważne jest tutaj odpowiednie dobranie określonych zagadnień, biorąc pod uwagę ich doniosłość dla problemu badawczego.

W przypadku analizy karnoprawnej określonego przestępstwa (typu czynu zabronionego pod groźbą kary) konieczne jest zastosowanie powszechnie przyjętego sposobu analizy na podstawie danych grup znamion typu czynu (przedmiot ochrony, podmiot czynu, strona przedmiotowa czynu [w tym: czynność sprawcza, przedmiot czynności sprawczej, okoliczności czynności sprawczej oraz skutek czynności sprawczej], strona podmiotowa czynu).

2. Metoda badawcza. Jest to przyjęty przez autora sposób wyjaśniania problemu badawczego, czy też wyjaśniania przedmiotu analizy (najczęściej 
określonego przepisu prawa). Kategorycznie należy stwierdzić, że każdy naukowiec powinien posługiwać się świadomie i umiejętnie określoną metoda badawczą. W każdym razie powinien ja w swoim opracowaniu zgłosić. Jest bowiem oczywiste, że przyjęty sposób analizy problemu determinuje rozstrzygnięcia naukowe w takim samym stopniu jak sama treść problemu.

W rodzimej nauce prawa karnego dominuje metoda dogmatyczna, tzn. zorientowana na przepis prawny (który jest w prawie karnym dogmatem - stąd nazwa metody). W tym znaczeniu można wskazać, że to przedmiot analizy determinuje jej metodę. Rodzima doktryna prawa karnego zajmuje się przede wszystkim przepisami prawa i w konsekwencji ma charakter dogmatyczny. W szczególności polscy naukowcy karniści (w tym również ja) tradycyjnie zajmują się przepisami w głównej mierze na płaszczyźnie ich ustawowej treści. Jest to maniera klasyczna. Jednakże nie sposób uniknać wrażenia, że obecnie jest ona realizowana ilościowo i jakościowo w sposób niemal skrajny. Z jednej strony jest to usprawiedliwione i właściwe, ponieważ prawo karne to przepisy ustawy. Z drugiej jednak - samo badanie treści przepisu karnoprawnego ma charakter tyleż statyczny, co w znacznej mierze bezużyteczny. I nie chodzi tutaj już o to, że doniosłość takich badań jest praktycznie ograniczona, lecz o to, że na płaszczyźnie wyłącznie teoretycznej walor poznawczy jest tutaj po prostu skromny. Do rzadkości należą prace karnoprawne o charakterze interdyscyplinarnym (materialnym, a także: procesowym, „wykonawczym”, polityczno-kryminalnym, kryminologicznym czy też kryminalistycznym). Brak tutaj dynamicznego ujęcia deliktu ustawowego, przy czym nie chodzi o jego ujęcie praktyczne (law in action), lecz wciąż teoretyczne (law in book), jednakże uwzględniające szerszy kontekst przepisu, a nie tylko jego treść.

Opracowanie naukowe $\mathrm{z}$ reguły zawiera wykładnię naukową (w odróżnieniu od innych rodzajów wykładni: autentycznej, legalnej i sądowej). Wykładnia taka z reguły opiera się na derywacyjnej metodzie wykładni (w odróżnieniu od metody klaryfikacyjnej). Interpretacja karnistyczna (dogmatyczna, derywacyjna metoda wykładni karno-naukowej) jest realizowana na dwóch płaszczyznach, a właściwie w dwóch etapach. W pierwszej kolejności znamiona ustawowe danej instytucji prawa karnego sa objaśniane statycznie (tj. na podstawie określonych reguł wykładni: językowej, logicznej, systemowej, celowościowej lub historycznej). W drugiej kolejności określony przepis prawa może być dodatkowo poddany interpretacji dynamicznej, zgodnie z tzw. teoria norm sprzężonych, sprowadzająca się do identyfikacji i funkcjonowania normy sankcjonowanej oraz sankcjonującej. W rodzimej doktrynie prawa karnego powyższe dwa ujęcia są nierzadko sobie przeciwstawiane. Należy jednak uznać, że w istocie nie tylko nie są one wzajemnie sprzeczne, lecz się uzupełniaja, umożliwiając pełniejsza, dogmatyczną analizę instytucji prawa karnego.

W każdym razie recenzent powinien dokonać oceny zastosowanej przez autora metody interpretacji karnistycznej. Odpowiednie posługiwanie się zasadami takiej interpretacji to jeden z głównych wyznaczników umiejętności badacza karnisty.

3. Koncepcja prawa. Obecne prawo karne to swoisty tygiel różnych dotychczasowych koncepcji na temat prawa karnego i jego podstawowych części. 
W związku z tym naturalne i uprawnione jest przyjęcie subiektywnej w tym zakresie wizji przez danego autora. Niemal zawsze karnista badajacy prawo karne reprezentuje określoną koncepcje prawa karnego. Problematyka koncepcji prawa jest szeroka i obejmuje różne zagadnienia, począwszy od określonej polityki prawa karnego, poprzez filozofię prawa karnego (w zakresie podstaw odpowiedzialności penalnej oraz reakcji karnoprawnej, np. bardziej klasyczny albo bardziej utylitarny), a skończywszy na określonej (przyjętej i stosowanej przez autora) strukturze przestępstwa. Należy oczywiście skonstatować, że szczegółowe problemy badawcze nie wymagaja od autora deklaracji w zakresie podstawowych zagadnień prawa karnego. Jednak już chociażby krótka deklaracja w zakresie przyjętej struktury przestępstwa wydaje się konieczna niemal w każdym opracowaniu. Pozwala to bowiem z jednej strony odpowiednio sformułować i rozwiązać problem badawczy, a z drugiej - zrozumieć odbiorcy wywody autora.

4. Wars ztat na ukowy. W tym, jakże ważnym aspekcie metodyki badań naukowych, należy wyróżnić wymiar formalny i merytoryczny. Z formalnego punktu widzenia istotna jest ocena jakości języka i stylu prowadzonych rozważań. Chodzi przy tym nie tylko o używany przez autora język prawniczy, lecz również powszechny (naukowy). Tok wywodów powinien być językowo w pełni zrozumiały. Należy unikać zdań nazbyt rozbudowanych, neologizmów i zapożyczeń z innych języków. Elokwencja autora nie przejawia się w kwiecistym języku, lecz w logice argumentacji. W omawianym aspekcie formalnym należy również ocenić dbałość redakcyjną autora, czyli redagowanie tekstu (w tym akapitów), przypisów, śródtytułów (itd. itp.). Tekst redakcyjnie niedbały może zniweczyć nawet bardzo dobre merytorycznie opracowanie.

Warsztat naukowy autora należy również ocenić pod względem merytorycznym. W tym aspekcie szczególną uwagę należy zwrócić na dwie kwestie: umiejętność zgromadzenia i wykorzystania źródeł oraz umiejętność formułowania i rozwiązywania problemów karnoprawnych. W pierwszym przypadku ważne jest zebranie wszystkich źródeł spośród literatury i orzecznictwa przedmiotu, a następnie odpowiednie ich wykorzystanie. Tutaj nierzadko pojawiaja się liczne uchybienia. Po pierwsze, autor opracowania nie zauważa, że cytowane źródło samo jest - w sposób pośredni albo bezpośredni - cytatem, czyli nie jest źródłem pierwotnym. Po drugie, przywołane źródło nie koresponduje merytorycznie z tokiem rozważań. Po trzecie, źródło jest przez autora zmanipulowane, ponieważ cytowana myśl jest wyrwana z kontekstu i w rzeczywistości nie potwierdza rozważań autora. Po czwarte, źródło jest na dany temat w literaturze przedmiotu drugorzędne, tzn. funkcjonują źródła ważniejsze i merytorycznie bardziej odpowiednie.

Merytoryczna ocena warsztatu naukowego autora powinna również dotyczyć jego umiejętności formułowania i rozwiązywania problemów karnoprawnych (czego nie należy mylić z prowadzoną przez niego wykładnią instytucji prawnokarnej). Stan pożądany w omawianym zakresie to zwięzły, spójny, logiczny i korespondujący z hipotezą badawczą wywód prawniczy. Należy tutaj pamiętać, że - jak już wspomniano powyżej - praca naukowa nie może mieć charakteru opisowej lub odtwórczej relacji, lecz polega na rozwiązaniu okre- 
ślonego problemu badawczego (weryfikacji postawionej hipotezy badawczej). Jest to tymczasem możliwe tylko wtedy, gdy autor potrafi między innymi formułować kolejne cząstkowe problemy, stawiać kolejne szczegółowe hipotezy, a następnie je merytorycznie weryfikować.

Odnosząc się do powyższych elementów opracowania naukowego i jego recenzji, należy podkreślić, że nie wszystkie one są obowiązkowe, choć zazwyczaj powinny znaleźć się w takim opracowaniu (i recenzji). Elementy te przedstawiają ujęcie ilościow e recenzji, tymczasem powinna ona zawierać również elementy jakościowe, czyli wskazywać określony poziom metodologii i metodyki, prezentowany w recenzowanym opracowaniu. Każdy z nich powinien być oceniony w odpowiedniej skali, przy czym:

1) łączna waga elementów metodologicznych i metodycznych powinna być zasadniczo równoważna;

2) nie wszystkie one powinny być rozpatrywane osobno (należy je łączyć w odpowiednie grupy elementów recenzyjnych);

3) w przypadku gdy którykolwiek z nich zasługuje na ocenę negatywna, wtedy taką końcową konkluzję powinna mieć również recenzja.

W ostatnim przypadku negatywna ocena może wynikać z braku lub błędu, który autor może usunać (przy recenzji negatywnej warunkowej) albo nie może tego uczynić lub uchybienie ma charakter dyskwalifikujący (przy recenzji negatywnej bezwarunkowej).

Cała przedstawiona metodologia i metodyka recenzowanego opracowania to jednak tylko szkielet pracy naukowej. Jej ciałem i umysłem jest rozwiązanie przez autora podjętego problemu naukowego. Może on bowiem przeprowadzić swoje rozważania pod względem metodologicznym i metodycznym bez zarzutu, a nie wzbogaci nauki w żaden sposób. Dlatego w recenzji ważne jest dodatkowe zawarcie merytorycznej oceny rozwiązania problemu badawczego i weryfikacja postawionej hipotezy badawczej. Jest to ocena naukowej jakości analizy. Wydaje się przy tym, że powinien to być odrębnie punktowany element recenzji o wadze odpowiadającej co najmniej połowie wagi wszystkich pozostałych elementów.

Kwestia dyskusyjną jest uznanie, ile łącznie punktów powinno stanowić o minimum dopuszczajacym opracowanie do publikacji. Wydaje się, że jest to co najmniej połowa wszystkich walorów, czyli „punktów” (min. 50\%), bez względu na rangę czasopisma naukowego (co oczywiście nie ma ścisłego związ$\mathrm{ku}$ z ministerialna punktacją danego czasopisma).

Redakcje zamawiajace recenzję zgłoszonego do czasopisma opracowania naukowego nierzadko proszą recenzenta także o sprawdzenie antyplagiatowe. Wydaje się, że zadanie to powinno być realizowane przez sama redakcję, już na etapie przyjęcia artykułu do recenzji. Uwaga to dotyczy również innych aspektów artykułu, takich jak: właściwa (minimalna i maksymalna) objętość, stosowany zapis (czcionka i interlinie) oraz inne podstawowe wymogi redakcyjne (np. zapis źródeł i wykaz literatury). To również redakcja już na wstępnym etapie powinna sprawdzać, czy zgłoszony artykuł swoją treścią koresponduje z charakterem danego czasopisma. 
W podsumowaniu należy stwierdzić, że sporządzenie recenzji opracowania, zgłoszonego do czasopisma naukowego, to zabieg niemal w pełni merytorycznie i formalnie zdeterminowany (koniecznymi elementami samego opracowania). Nawet jednak taki sposób ujęcia nie usuwa w tej mierze kwestii najważniejszej, czyli materialnej oceny dokonywanej przez danego recenzenta. Zabieg ten powinien być oczywiście obiektywny, co jednak nie zmienia faktu, że pozwala on w znacznej mierze zachować ściśle ocenny charakter recenzji. Dwie recenzje rozpatrywane przez redakcję łącznie pozwalają na stworzenie względnie obiektywnego obrazu wartości opracowania.

W nawiązaniu do powyższych uwag, w załączeniu przedstawiono autorski formularz recenzji z propozycjami odpowiedniego ujęcia ilościowego i jakościowego metodologii oraz metodyki.

\section{Załącznik}

\begin{tabular}{|c|c|c|}
\hline Lp. & Elementy recenzowanego opracowania & $\begin{array}{c}\text { Ocena jakościowa } \\
\text { (pkt) }\end{array}$ \\
\hline 1. & $\begin{array}{l}\text { Metodologia (I) } \\
\text { - znaczenie tytułu, } \\
\text { - zakres, znaczenie (teoretyczne i praktyczne) oraz aktualność } \\
\text { tematyki } \\
\text { Dodatkowe uwagi: }\end{array}$ & $0-10$ \\
\hline 2. & $\begin{array}{l}\text { Metodologia (II) } \\
\text { - problem badawczy i hipoteza badawcza, } \\
\text { - założenia badawcze, przedmiot analizy oraz terminologia } \\
\text { Dodatkowe uwagi: }\end{array}$ & $0-10$ \\
\hline 3. & $\begin{array}{l}\text { Metodyka (I) } \\
\text { - struktura analizy, } \\
\text { - metoda badawcza i koncepcja prawa } \\
\text { Dodatkowe uwagi: }\end{array}$ & $0-10$ \\
\hline 4. & $\begin{array}{l}\text { Metodyka (II) } \\
\text { - warsztat naukowy (merytoryczny i formalny) } \\
\text { Dodatkowe uwagi: }\end{array}$ & $0-10$ \\
\hline 5. & $\begin{array}{l}\text { Ocena naukowej jakości opracowania } \\
\text { (rozwiązania problemu badawczego) } \\
\text { Dodatkowe uwagi: }\end{array}$ & $0-20$ \\
\hline 6. & $\begin{array}{l}\text { Podsumowanie (łączna liczba punktów) } \\
\text { Dodatkowe uwagi: }\end{array}$ & $0-60$ \\
\hline
\end{tabular}




\section{HOW TO PEER-REVIEW A STUDY FROM THE FIELD OF CRIMINAL LAW STUDY}

\section{Sum mary}

The article describes the proper way to review scientific work from the field of the penal sciences. It includes an outline and discussion of all the necessary elements of a scientific review. The appropriate methodology of a criminal-law scientific study is also presented. Finally, a model for an optimal scientific review is proposed.

Keywords: criminal law; penal sciences; methodology and methodics of a scientific study; review of a scientific article; methodology and methodics of a scientific article; the structure of a scientific research 


\section{INFORMACJE DLA AUTORÓW}

1. Objętość nadsyłanych tekstów nie może przekraczać 1 ark. wyd. (36-40 tys. znaków wraz ze spacjami i przypisami) w wypadku artykułu. Obliczając objętość tekstu, należy wziąć pod uwagę, że obejmuje ona również wykaz cytowanej literatury, a także tabele i ryciny. Objętość recenzji nie powinna przekraczać 10 tys. znaków.

2. Zgłaszany tekst powinien być zanonimizowany $-\mathrm{z}$ tekstu głównego i przypisów, a także z metadanych pliku należy usunąć wszelkie informacje pozwalające zidentyfikować autora/autorów (np. o grantach).

3. W zgłoszeniu należy podać dane o autorze/autorach, adres do korespondencji, numery telefonów i adres służbowej (instytucjonalnej) poczty elektronicznej, a także identyfikator ORCID. W wypadku pracowników naukowych prosimy także o podanie nazwy i adresu uczelni macierzystej.

4. Teksty należy przesyłać za pośrednictwem platformy elektronicznej: https://pressto.amu.edu.pl/index.php/rpeis/about/submissions.

5. Wszelkie tabele, wykresy lub ryciny będące częścią tekstu należy również przesyłać w formie edytowalnego zapisu elektronicznego. Minimalna grubość linii rysunku powinna wynosić 0,4 pkt, a rysunki należy sporządzić w formacie nie większym niż format kolumny $(126 \times 180 \mathrm{~mm})$.

6. Do artykułu należy dołączyć krótkie streszczenia (abstrakty) w języku polskim i angielskim (ok. 1,5 tys. znaków) oraz słowa kluczowe.

7. Do przesłanej propozycji publikacji należy dołączyć oświadczenie (dostępne na: www.rpeis.pl). Po przyjęciu tekstu do druku autor podpisuje umowę wydawniczą z czasopismem.

8. Termin wykonania korekty autorskiej wynosi maksymalnie 1 tydzień. Po upływie tego terminu tekst kierujemy do publikacji wyłącznie z korekta redakcyjna.

9. Zgłoszenie artykułu, proces recenzyjny oraz publikacja w RPEiS są bezpłatne.

10. Publikacja w RPEiS oznacza zgodę na zdeponowanie tekstu w wersji elektronicznej w repozytoriach, bazach i na platformach indeksujących i upowszechniających treści naukowe.

Szczegółowe zasady edytorskie dostępne na www.rpeis.pl 


\section{SUBMISSION GUIDELINES}

1. The length of manuscripts submitted to RPEiS must not exceed 36,00040,000 characters (6,000 words), including spacing and footnotes, reference list, and tables and figures, in the case of articles, and a maximum of 10,000 characters (1,500 words) for reviews.

2. The submitted text should be anonymized - any information making it possible to identify the author(s) (for example, concerning grants) should be removed from the main text and footnotes, as well as from the file metadata.

3. The author's personal details, correspondence address, telephone numbers and institutional email address as well as ORCID identifier must be attached. In the case of academic staff, we also request the name and address of their university.

4. Manuscripts should be submitted via https://pressto.amu.edu.pl/index. php/rpeis/about/submissions.

5. All tables, graphs or graphics in the body of the text must be sent in enable-editing electronic form. The minimum line width should be $0.4 \mathrm{pts}$ and figures should be in a form that does not exceed the format of a $128 \times 180 \mathrm{~mm}$ column.

6. A short abstract, in Polish and English, must be attached (1,500 characters/ 250 words) with a list of keywords.

7. A declaration must be attached to the application for publication (available at www.rpeis.amu.edu.pl). After the text has been accepted for publication, the author will sign a publishing agreement with the journal.

8. The deadline for authors' revisions is one week. Thereafter the manuscript will be sent for publication with the editors' revisions only.

9. There are no fees for submitting, processing or publishing an article in RPEiS.

10. Publication in RPEiS implies that the author consents to the electronic location of the text in repositories, databases and platforms indexing and disseminating scientific content.

More on editorial principles at www.rpeis.pl 
